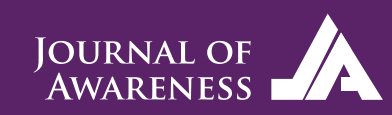

8
Journal of Awareness

Volume / Cilt: 6, Issue / Sayl:4, 2021, pp. 197-211

E-ISSN: 2149-6544

https://journals.gen.tr/joa

DOI: https://doi.org/10.26809/joa.6.4.02
Received / Geliș: 03.08.2021 Accepted / Kabul: 26.09.2021

\title{
Aksaray-Ortaköy ilçesi Hacı İbrahim Uşağ1 köyü Kirkitli dokuma örnekleri
}

\author{
Kirkitli weaving samples of Haci Ibrahim Uşaği \\ village, Aksaray-Ortakoy district
}

\section{Semra Kılıç Karatay}

Dr. Öğr. Üyesi, Aksaray Üniversitesi, Eğitim Fakültesi, Güzel Sanatlar Öğretimi, Resim-İş Öğretmenliği, İstanbul, Türkiye , e-mail: semra.kilic@hotmail.com

Öz

Halı kilim dokumaları kirkitli dokuma örnekleri olarak da bilinmektedir. Halı ve kilim dokumasının tarihi çok eskidir. Dokumacılık, insanların günlük yaşamda ihtiyaç duydukları önemli unsurlardan olduğu bilinmektedir. Dokuma sanatında elimize ulaşan örnekler en değerli kültür ögeleri olup belge niteliği taşımaktadır. Dokunduğu dönemin tarihi, kültürü veya medeniyeti hakkında bilgi veren önemli belge niteli taşımaktadırlar. Toplumu oluşturan bireylerin eski zamanlarda yaşadıkları evlerin yer ve duvarlarında, çadırların üstlerini ve kapılarını örtmede, çadır içlerinin sergisinde, ev veya çadırların içinde ya da dışında oturmak veya yaslanmak için dokudukları farklı ebatlarda farklı teknik ve malzemelerle dokumacılık yaptıkları görülmektedir.

Aksaray ili Ortaköy ilçesine bağlı Hacı İbrahim Uşağı köyünde alan araştırma yapılmış dokuma örneği bulunan evler tespit edilmiş ve elde edilen örnekler incelenmiştir. Elde edilen dokuma örnekleri halı ve düz dokuma örnekleri iki grupta ele alınmıştır. Dokuma örnekleri halı ve düz dokuma örnekleri olarak iki grupta incelenmiştir. Halı ve düz dokuma örnekleri ölçülerine veya kullanım alanlarına göre sınıflandırılması yapılmıştır. Alan araştırması kapsamında sözlü görüşme metodu ile dokumalar hakkında bilgi edinilerek gün yüzüne çıkmamış dokuma örneklerinin literatüre kazandırılmasına önem verilmiştir.

Anahtar kelimeler: Dokuma, Halı, Kilim, Ortaköy, Aksaray

\section{Abstract}

Carpet rug weaving samples are also known as kirkit weaving samples. The history of carpet and rug weaving is very old. It is known that weaving is one of the important elements that people need in daily life. The examples we have in the art of weaving are the most valuable cultural elements and have the quality of historical documents. They are important documents that give information about the history, culture or civilization of the period they touched. It is seen that the individuals who make up the society are weaving with different techniques and materials in different sizes, on the floors 
and walls of the houses they lived in, in covering the tops and doors of the tents, in the exhibition of the tent interiors, in order to sit or lean inside or outside the houses or tents.

In the village of Hacı İbrahim Uşak, in the Ortaköy district of Aksaray province, the field research was carried out, the houses with weaving samples were determined and the samples obtained were examined. The weaving samples obtained, carpet and plain weaving samples were handled in two groups. Weaving samples were examined in two groups as carpet and plain weaving samples. Carpet and plain weaving samples were classified according to their dimensions or usage areas. Within the scope of the field research, it was given importance to gain information about weavings with the verbal interview method and to bring the unearthed weaving samples to the literature.

Keywords: Weaving, Carpet, Kilim, Ortaköy, Aksaray

\section{GİRIŞ̧}

Dokuma sanatı en önemli kültür değerlerimizden biri olup, başlangıç tarihini gösteren belge bulunmamaktadır. Dokuma sanatı ile ilgili ilk araştırmalar 1891 yılında Viyana Halı Sergisi kitabının yayınlanması ile başladığı bilinmektedir.

İnsanoğlu tarihsel süreç içinde yaşamlarını sürdürebilmeleri için beslenmeye ve barınmaya ihtiyaç duymaktadır. Barınak olarak kullanılan ev, çadır ve buna benzer ikamet ettikleri yerlerde gerek yaygi gerekse süs eşyası olarak halı, kilim, yastık, çadır, çeyiz eşyaları gibi malzemelere ihtiyaç duymuş ve bu malzemeleri elde etmek içinde yün, pamuk, ipekten elde edilmiş iplerle dokunan dokumaları kullanmışlardır (Kılıç Karatay, 2018, s:23).

Halıcılığın ilk yurdunun neresi olduğu konusunda, yabancı araştırmacıların değişik yorumları vardır. Bunlardan bir kısmı, Erzurum dolaylarında bir ermeni şehri olan Kalıklay'ı, diğer bir kısım araştırmacılar ise İran'1 halının ilk yurdu olarak göstermişlerdir. Ancak kazılar sonucu ortaya çıkarılan halılar bu fikirleri çürütmüştür (Yetkin,1974, s:12).

Düğümlü halılar ilk defa Türklerin bulunduğu bölgelerde ortaya çıkmış ve gelişmesini sürdürmüştür. Dügüumlü halıların tarihi Türk tarihine sıkıca bağlıdır. Türklerin bu ananevi sanatı yüzyıllardan beri yaşatılmış ve bir dokuma tekniğine tabi olarak gelişmesinde bu özelliğini muhafaza etmiştir (Yetkin, 1991, s: 1).

Türkler, konutlarında yaygın olarak halının dokunmasına büyük önem vermişlerdir. Çok eskiden her genç kız, evlendikten sonra oturacağı evi süsleyecek halıları kendi eliyle dokumak zorundaydı (Arseven, 1980, s: 123).
Daima Türkler'in yaşadığı ülkelerde ortaya çıkan halının tarihi, sıkı sıkıya Türkler'e bağlı olduğu gibi, Büyük Selçuklu Sultanlığı devrinde kurulan devletlerle, bunun tekniğini önce İslam alemine sonra bütün dünyaya tanıtan da Türkler olmuştur (Aslanapa, 2005, s:13).

Kültür olarak zengin değerlere sahip Anadolu insanı yüz yıllardır halı ve kilim dokuma alanında da kendini geliştirmiştir. Günümüze ulaşabilen örnekler bu kültürel zenginliğin en önemli kanıtıdır. Eski dönemlerden bu zaman kadar kültür zenginliğin örnekleri olan dokumalar insanoğlunun dokuma sanatı alanında yaratıcılığını göstermektedir. Halı ve kilim dokumacılığı yüzyılları aşan ve günümüze kadar ulaşan bir kültür kimlik öğesidir.

Dokuma atkı ve çözgü iplerinin birbirinin altından ve üstünden geçmesiyle elde edilen ürünlerdir. Dokuma sanatı sadece halı- kilim dokuma örneklerini değil aynı zamanda mekikli dokuma örneklerini de kapsamaktadır.

Yazılı kaynaklara göre Aksaray ve çevresi dokuma merkezi olarak bilinmektedir. Günümüze kadar ulaşabilen örneklerde bulunmaktadır. Hacı İbrahim Uşağı köyü Aksaray ilinin Ortaköy ilçesine bağlı bir köydür. Köyün geçmiş zamanlarda dokuma yaptığ 1 elde edilen örneklerden anlaşılmaktadır. Daha çok düz dokumaların dokunduğu elde edilen örneklerden anlaşılmaktadır.

Elde edilen düz dokuma örnekleri yer yaygısı, çuval ve heybe örnekleridir. Bu dokuma örneklerinde bezayağ1 olarak bilinen düz kilim dokuma tekniği ve cicim dokuma tekniğinin uygulandığı görülmektedir. Geleneksel motiflerimizden olan özellikle çuval dokuma- 
larda kompozisyonu oluşturan ve pitrak ve bereket motifi köyde "Çalma" motifi olarak adlandırılmaktadır. Düz dokuma örneklerinde kullanılan atkı, çözgü ve dokuma iplerinin hammaddesi yündür. Dokuma iplerinin renklendirilmesinde cevt, üzüm yaprağ ceviz kabuğu, soğan kabuğu ve vb. bitkilerden elde edilen doğal boyarmaddeler kullanılmıştır(Sergikaya, 2021).

Köyde elde edilen diğer dokumalar ise halı dokuma örnekleridir. Dokuma kompozisyonlarında renk ve desen olarak birlik bulunmamaktadır. Köyde dokuma yapan dokumacılar Taşpınar, Arısama ve Isparta yöresi dokuma örneklerini desen olarak kullanılmıştır. Köyde kendine ait özel bir desen veya motife rastlanmamıştır. Halı dokuma örnekleri genellikle yer yaygısı olarak kullanılan taban veya çeyrek yer halısı ve yastık dokuma örnekleridir.

Dokumalarda hammadde olarak yünün yanında pamuk ipleri de kullanılmıştır. Elde edilen dokuma örneklerinin bazılarının çözgüsünde pamuk, atkı ve dokuma iplerinde yün kullanılırken bazılarında ise tamamen yün kullanılmıştır. Yünlerin boyanmasında erik, üzüm yaprağı cevt, erik, soğan kabuğu gibi doğal boyar maddelerin yanında sentetik toz boyarmaddelerde kullanılmıştır (Çiftçi, 2021).

\section{HACIİBRAHİM UŞAĞI KİRKITTLI DOKUMA ÖRNEKLERİ}

\subsection{Düz Dokuma Örnekleri}

Köyde alan araştırması ile 28 adet düz dokuma örneği elde edilmiştir. Dokumalar eskiden dokunmuş ve miras olarak günümüze ulaşmıştır. Günümüzde köyde dokuma yapılmamaktadır. Düz dokuma örnekleri yer yaygısı, çuval ve heybe dokuma örnekleridir. Dokumaların zamanla renklerinin solmuş olması dokunma tarihlerinin oldukça eski olabileceği görüşünü ortaya koymaktadır. Düz dokumalarda zamanla meydana gelen yıpranma ve yırtılmalarda bu düşünceyi desteklemektedir. Dokumalarda yer yaygısı olarak bilinen düz dokuma örnekleri kilim yani bez ayağı tekniği ile dokunmuş olup, heybe ve çuvallarda kilim dokuma üzerine Cicim sarma tekniği ile desen oluşturulduğu görülmektedir. Dokumaların özellikle heybe ve çuval örneklerinin desen zenginliği dikkat çekmektedir. Desen kompozisyonlarında pitrak ve bereket motifinin sık kullanıldığı görülmektedir.

Düz dokuma örneklerinde ham madde olarak yün kullanılmaktadır. Köyde bulunan dokuma sahipleri dokuma örneklerinde kullanılan desen ipliklerinin dokumayı yapan büyükleri tarafından doğal yollarla boyandığ ${ }_{1}$ belirtmişlerdir(Sergikaya, 2021).

Düz dokuma örneklerini kullanım alanlarına göre sinıflandırarak, günümüzdeki durumu, kullanılan malzeme ve teknik açısından değerlendirilmesi yapılarak incelenmiştir. Yer yaygı dokuma örneklerinde Şak olarak bilinen dokuma örnekleri iki parça halinde dokunup daha sonra çoban dikişi olarak bilinen özel bir dikişle birbirine dikilerek kullanılmaktadır (Çiftçi, 2021).

Dokumaların çoğunlukla yanlış kullanılması dokumalarda yırtılmalara sebep olmuş ve yırtılan bölgeler daha sonra tığ veya mil ile elde edilen parçalarla yamanarak kullanılmaya devam etmiştir.

\subsubsection{Yer Yayg1sı Örnekleri}

Fotoğraf 1.Yer Yayg1sı Dokuma Örneği
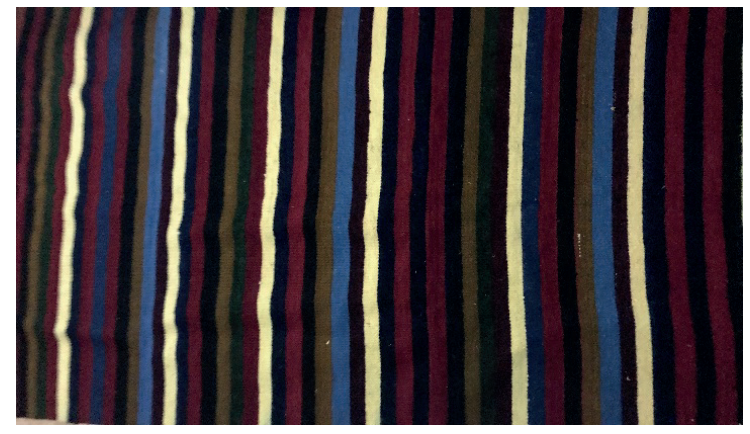

Kaynak: Kılıç Karatay, 2021

Örnek 1.

Dokumanın Bulunduğu Yer: Hacı İbrahim Uşağ Köyü Dokumanın Yöredeki İsmi: Yer kilimi

Dokumanın Yapıldığı Yıl:2000

Dokumada Kullanılan Malzeme: Yün

Kullanılan Motifler: su yolu

Dokumanın Türü: Düz Dokuma

Dokumanın Tekniği: Bez ayağı 
Fotoğraf 2. Yer Yayg1sı Dokuma Örneği

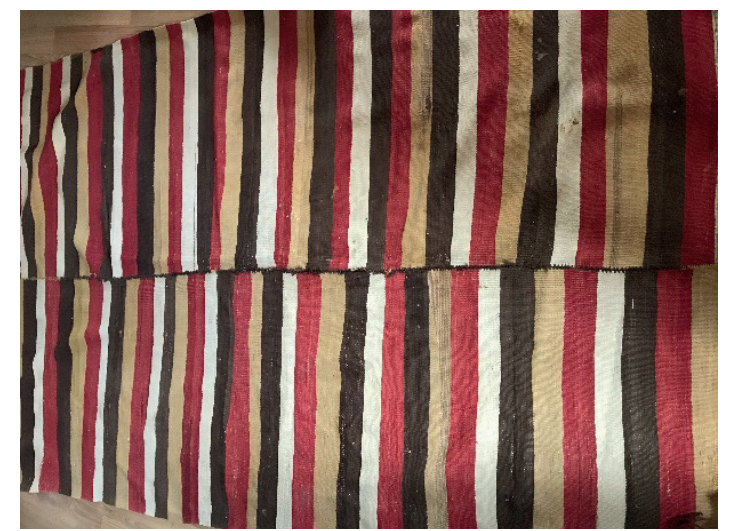

Kaynak: Kılıç Karatay, 202

Örnek 2.

Dokumanın Bulunduğu Yer: Hacı İbrahim Uşağı Köyü Dokumanın Yöredeki İsmi: Şak kilimi

Dokumanın Yapıldığı Yıl: 1995

Dokumada Kullanılan Malzeme: Yün

Kullanılan Motifler: Su yolu

Dokumanın Türü: Düz Dokuma

Dokumanın Tekniği: Bez ayağı

Fotoğraf 3.Yer Yaygısı Dokuma Örneği

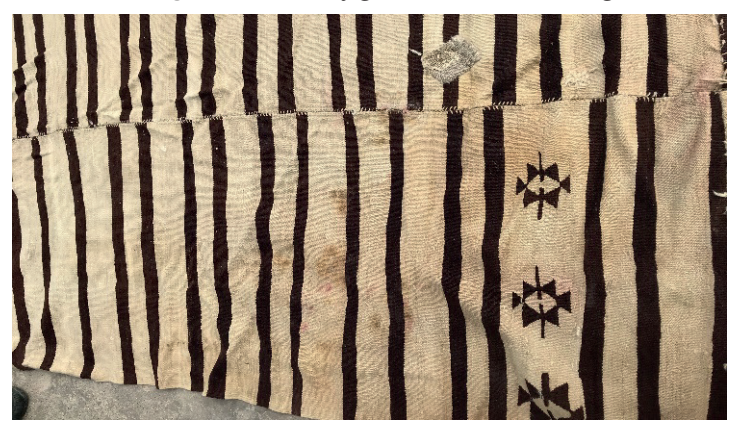

Kaynak: Kılıç Karatay, 2021

\section{Örnek 3.}

Dokumanın Bulunduğu Yer: Hacı İbrahim Uşağı köyü

Dokumanın Yöredeki İsmi: Şak kilim

Dokumanın Yapıldığı Yıl: 1960

Dokumada Kullanılan Malzeme: Yün

Kullanılan Motifler: bukağı, göz, su yolu

Dokumanın Türü: Düz Dokuma

Dokumanın Tekniği: Bez ayağı

\subsection{2.Çuval Dokuma Örnekleri}

Genelde tahıl ve baklagillerin saklanması için dokuna örnekleri günümüzde işlevini kaybetmiştir. Günümüzde dekorasyon süs eşyası olarak kullanılan çuval dokuma örnekleri incelendiğinde zamanla yıpranmış ve yırtılma meydana geldiği gözlemlenmiştir.Elde edilen dokuma örnekleri incelendiğinde dokuma örneklerinin yapılma zamanının eski olduğu görülmektedir.

Dokumaların sahipleri dokuma örneklerinin genellikle babaanne veya anneannelerinden miras olarak kaldığını ifade etmektedirler. Günümüzde köyde herhangi bir dokuma yapılmadığ 1 ve eskiden kalan dokuma örneklerinin de satılarak veya makine halısıyla değişim yapılarak değerlendirildiği görülmektedir (Kocagül, 2021).

Çuval dokuma örneklerinde köyde Çalma adı verilen motifin hakim olduğu görülmektedir. Çalma motifi yazılı kaynaklarda Pıtrak ve Bereket motifi olarak geçmektedir (Sergikaya, 2021).

Eskiden dokuma yapan dokumacılar doğadaki nesneleri dokumaların desen kompozisyonunda motif olarak kullanmışlardır.

Fotoğraf 4. Çuval Dokuma Örneği

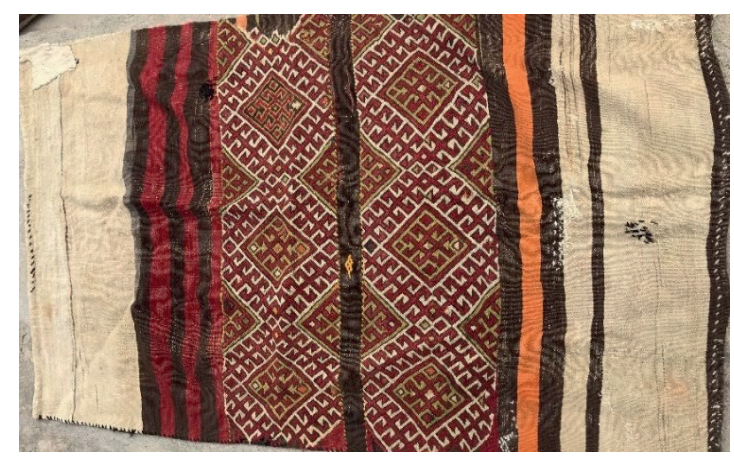

Kaynak: Kılıç Karatay, 2021

Örnek 1.

Dokumanın Bulunduğu Yer: Hacı İbrahim Uşağ Köyü Dokumanın Yöredeki İsmi: Çuval dokuması Dokumanın Yapıldığı Yıl: 1950

Dokumada Kullanılan Malzeme: Yün

Kullanılan Motifler: Bereket, elibeline, koç boynuzu, su yolu Dokumanın Türü: Düz Dokuma

Dokumanın Tekniği: Cicim 
Fotoğraf 5. Çuval Dokuma Örneği

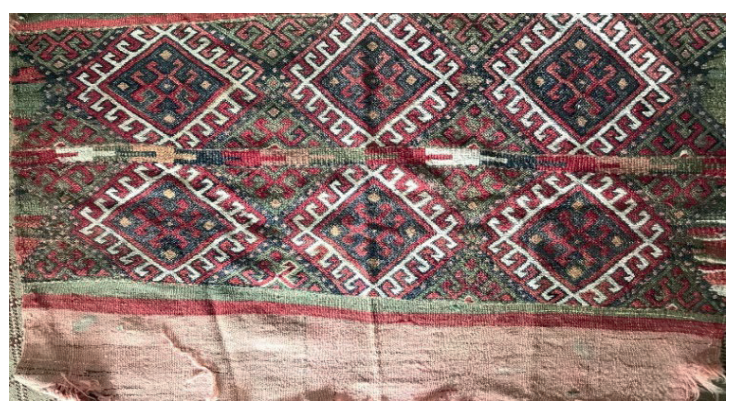

Kaynak: Kılıç Karatay, 2021

Örnek 2.

Dokumanın Bulunduğu Yer: Hacı İbrahim Uşağı Köyü Dokumanın Yöredeki İsmi: Çuval dokuması

Dokumanın Yapıldığı Yıl: 1965

Dokumada Kullanılan Malzeme: Yün

Kullanılan Motifler: Bereket, elibeline, koç boynuzu

Dokumanın Türü: Düz Dokuma

Dokumanın Tekniği: Cicim

Fotoğraf 6. Çuval Dokuma Örneği

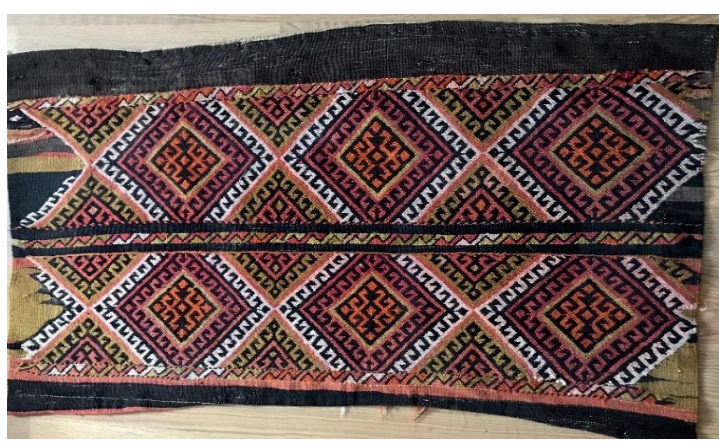

Kaynak: Kılıç Karatay, 2021

\section{Örnek 3.}

Dokumanın Bulunduğu Yer: Hacı İbrahim Uşağı Köyü

Dokumanın Yöredeki İsmi: Çuval dokuması

Dokumanın Yapıldığı Yıl: 1989

Dokumada Kullanılan Malzeme: Yün

Kullanılan Motifler: Bereket, elibeline, koç boynuzu

Dokumanın Türü: Düz Dokuma

Dokumanın Tekniği: Cicim
Fotoğraf 7. Çuval Dokuma Örneği

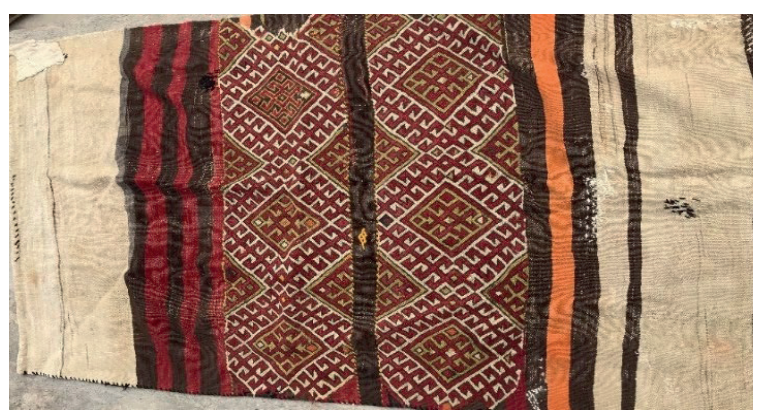

Kaynak: Kılıç Karatay, 2021

Örnek 4.

Dokumanın Bulunduğu Yer: Hacı İbrahim Uşağı Köyü

Dokumanın Yöredeki İsmi: Çuval dokuması

Dokumanın Yapıldığı Yıl: 1955

Dokumada Kullanılan Malzeme: Yün

Kullanılan Motifler: Bereket, elibeline, koç boynuzu, su yolu Dokumanın Türü: Düz Dokuma

Dokumanın Tekniği: Cicim

Fotoğraf 8. Çuval Dokuma Örneği

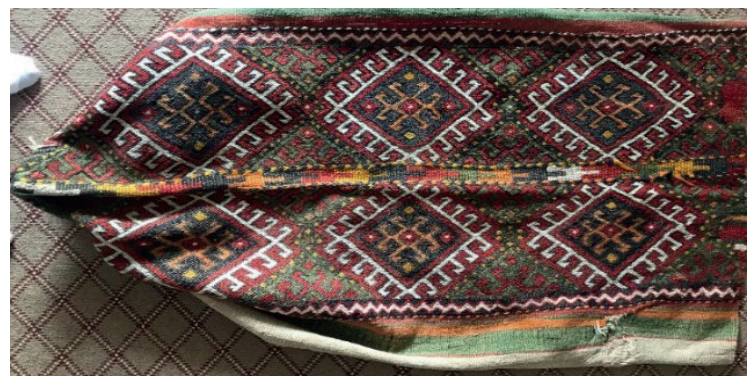

Kaynak: Kılıç Karatay, 2021

Fotoğraf 9.Çuval Dokuma Örneği

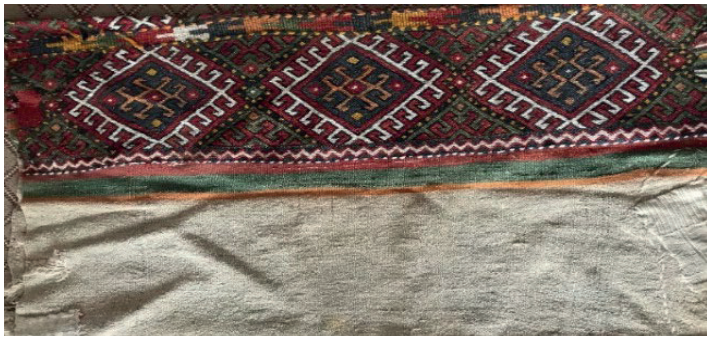

Kaynak: Kılıç Karatay, 2021

Örnek 5.

Dokumanın Bulunduğu Yer: Hacı İbrahim Uşağı/ Ortaköy İlçesi

Dokumanın Yöredeki İsmi: Çuval dokuması

Dokumanın Yapıldığı Yıl: 1985

Dokumada Kullanılan Malzeme: Yün

Kullanılan Motifler: Bereket, elibeline, koç boynuzu

Dokumanın Türü: Düz Dokuma

Dokumanın Tekniği: Cicim 


\subsubsection{Heybe Dokuma Örnekleri}

Köyün bir zamanlar tarım ve hayvancılık önemli geçim kaynaklarından olup günümüzde azalmıştır. Eskiden hayvanların sırtında yiyecek veya yük taşımak için dokunan heybe dokuma örnekleri günümüzde iki tekerli araçlarda kullanılmakta veya evlerde duvarlarda süs eşyası olarak kullanılmaktadır.

Heybe dokumaların göz kısımları genellikle kilim dokuma üzerine cicim tekniği ile elde edilen kompozisyonlarla dokunmuş, sırt kısımları ise bez ayağ tekniğinde düz kilim olarak dokunmuştur (Sergikaya, 2021).

Dokumalarda göz, pıtrak, çengel, suyolu, elibelinde ve koçboynuzu gibi geleneksel motiflerimiz desen kompozisyonlarında kullanıldığı görülmektedir. Bazı dokuma örnekleri ise ilikli kilim tekniğinde dokunmuştur (Eğritaş, 2021).

Heybe dokumalarda anneanne veya babaanne hatta daha eski zamanlardan miras yoluyla günümüzdeki sahiplerine kalmıştır (Sergikaya, 2021).

Fotoğraf 10. Heybe Örneği

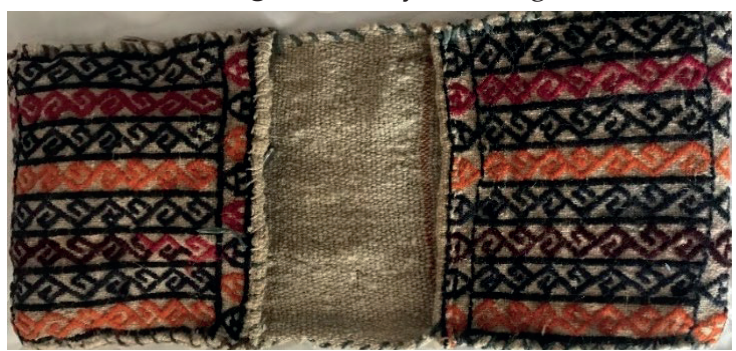

Kaynak: Kılıç Karatay, 2021

Fotoğraf 11. Heybe Örneği

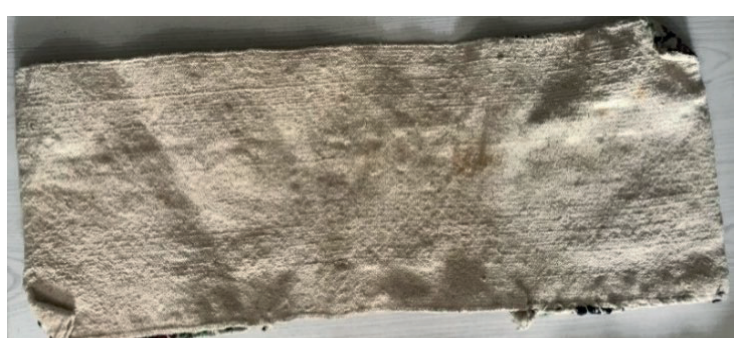

Kaynak: Kılıç Karatay, 2021

Örnek 1.

Dokumanın Bulunduğu Yer: Hacı İbrahim Uşağı köyü

Dokumanın Yöredeki İsmi: Heybe dokuması

Dokumanın Yapıldığı Yıl: 1985

Dokumada Kullanılan Malzeme: Yün

Kullanılan Motifler: Çengel, küpeli, su yolu

Dokumanın Türü: Düz Dokuma

Dokumanın Tekniği: Cicim

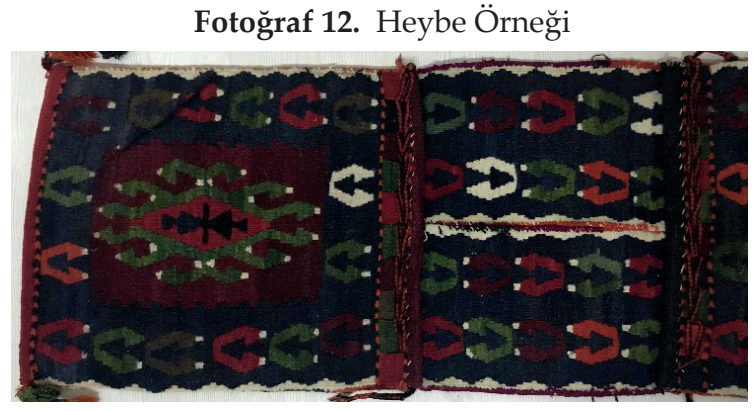

Kaynak: Kılıç Karatay, 2021

Fotoğraf 13. Heybe Örneği

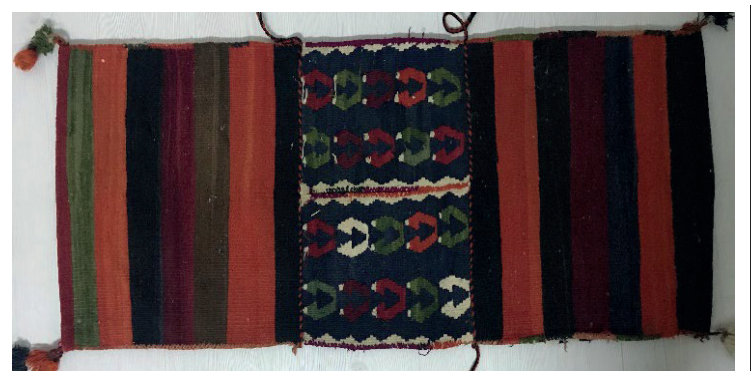

Kaynak: Kılıç Karatay, 2021

Örnek 2.

Dokumanın Bulunduğu Yer: Hacı İbrahim Uşağı köyü

Dokumanın Yöredeki İsmi: Heybe dokuması

Dokumanın Yapıldığı Yıl: 2000

Dokumada Kullanılan Malzeme: Yün

Kullanılan Motifler: Elibelinde, su yolu, bereket

Dokumanın Türü: Düz Dokuma

Dokumanın Tekniği: İlikli kilim

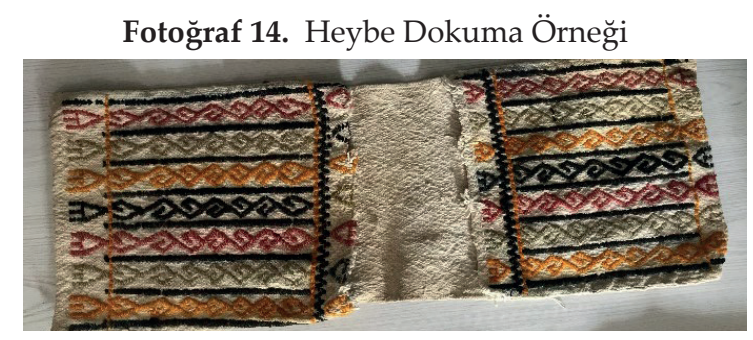

Kaynak: Kılıç Karatay, 2021

Fotoğraf 15. Heybe Dokuma Örneği

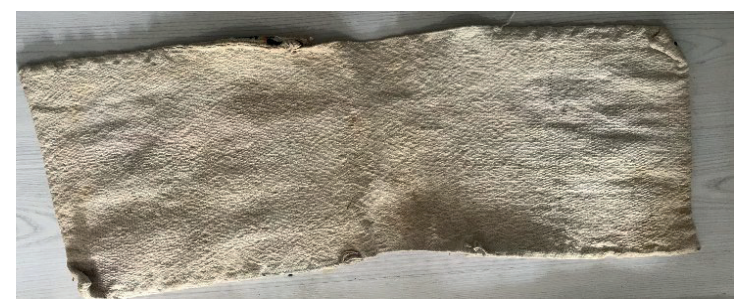

Kaynak: Kılıç Karatay, 2021

Örnek 3.

Dokumanın Bulunduğu Yer: Hacı İbrahim Uşağı/ Ortaköy 
İlçesi

Dokumanın Yöredeki İsmi: Heybe dokuması

Dokumanın Yapıldığı Yıl: 1984

Dokumada Kullanılan Malzeme: Yün

Kullanılan Motifler: Çengel, su yolu, küpeli

Dokumanın Türü: Düz Dokuma

Dokumanın Tekniği: Cicim

Fotoğraf 16. Çuval Dokuma Örneği
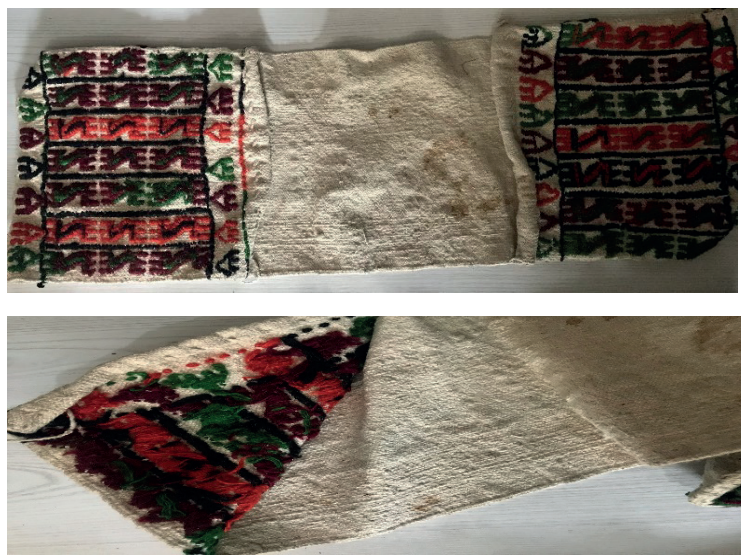

Kaynak: Kılıç Karatay, 2021

Örnek 4.

Dokumanın Bulunduğu Yer: Hacı İbrahim Uşağı/ Ortaköy İlçesi

Dokumanın Yöredeki İsmi: Çuval dokuması

Dokumanın Yapıldığı Yıl: 1987

Dokumada Kullanılan Malzeme: Yün

Kullanılan Motifler: Küpeli, su yolu

Dokumanın Türü: Düz Dokuma

Dokumanın Tekniği: Cicim

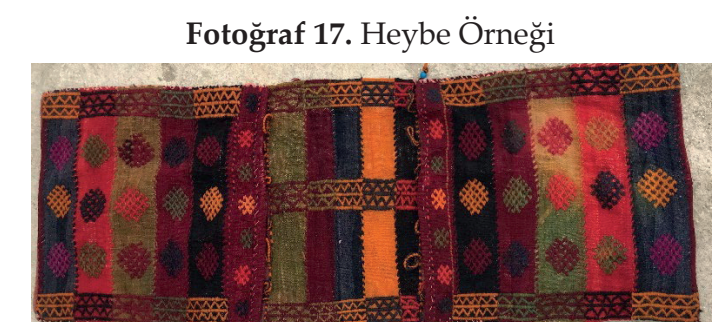

Kaynak: Kılıç Karatay, 2021

Fotoğraf 18. Heybe Örneği

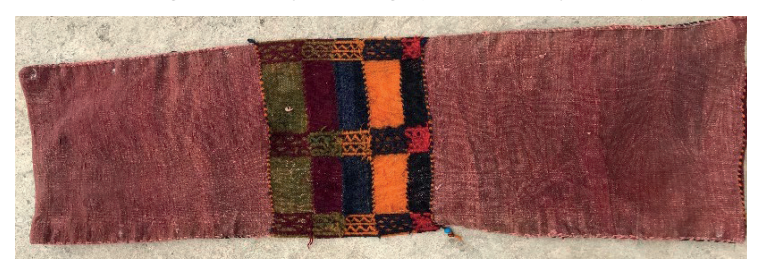

Kaynak: Kılıç Karatay, 2021

\section{Örnek 5.}

Dokumanın Bulunduğu Yer: Hacı İbrahim Uşağı köyü

Dokumanın Yöredeki İsmi: Heybe dokuması
Dokumanın Yapıldığı Yıl: 1982

Dokumada Kullanılan Malzeme: Yün

Kullanılan Motifler: Pıtrak, hayat ağacı

Dokumanın Türü: Düz Dokuma

Dokumanın Tekniği: Cicim

Fotoğraf 19. Heybe Dokuma Örneği

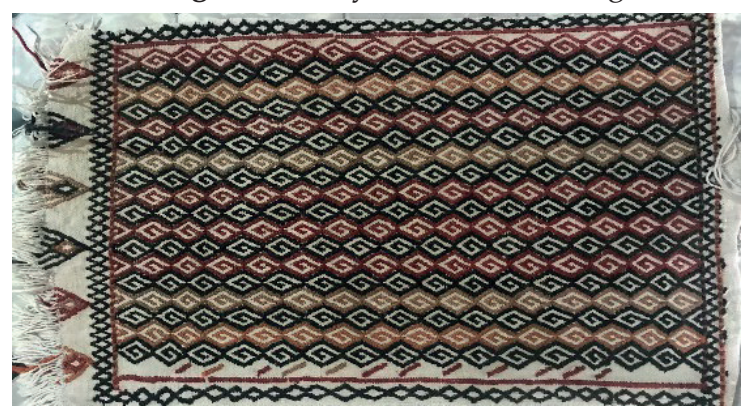

Kaynak: Kılıç Karatay, 2021

Örnek 6.

Dokumanın Bulunduğu Yer: Hacı İbrahim Uşağı köyü

Dokumanın Yöredeki İsmi: Heybe dokuması

Dokumanın Yapıldığı Yıl: 1981

Dokumada Kullanılan Malzeme: Yün

Kullanılan Motifler: Çengel, küpeli,su yolu

Dokumanın Türü: Düz Dokuma

Dokumanın Tekniği: Cicim

\subsection{Halı Dokuma Örnekleri:}

\subsubsection{Yer Halısı Dokuma Örnekleri}

Köyde bulunan halı dokuma örnekleri genellikle taban, çeyrek ve yastık dokuma örnekleridir. Köydeki halı dokumalarının desen ve renk kompozisyonları incelendiğinde farklı yörelere ait desen ve renk kompozisyonlarına yer verildiği görülmektedir. Aksaray yöresine ait Taşpınar dokumalarının yanı sıra Arısama, Isparta gibi bölgelere ait dokumaların desen olarak kullanıldığı görülmektedir(Altınpınar, 2021).

Dokumaların Isparta halılarında çözgüde pamuk kullanılırken diğer yörelere ait dokumalarda hammadde olarak yün kullanılmıştır. Halı dokumaların iplerinde ise sadece koyun yünü kullanılmıştır. Dokumaların birçoğu yakın tarihli olduğu gibi birçoğu da eski tarihli dokuma örnekleridir. Yer yaygısı olarak dokunan halı dokumalar sergi olarak kullanıldığ 1 için görsellerini almakta eksik kalınan noktalar bulunmaktadır (Duman, 2021). 
Fotoğraf 20. Dokuma Örneği

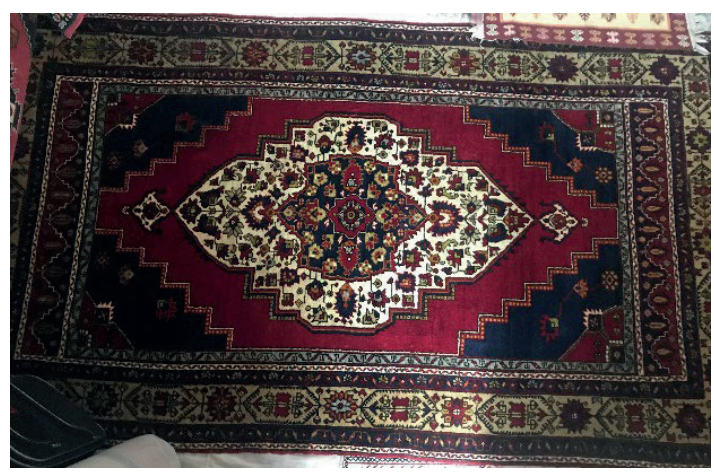

Kaynak: Kılıç Karatay, 2021

Örnek 1.

Dokumanın Bulunduğu Yer: Hacı İbrahim Uşağı köyü Dokumanın Yöredeki İsmi: Yer halısı

Dokumanın Yapıldığı Yıl: 1996

Dokumada Kullanılan Malzeme: Yün Kullanılan Motifler: Penç, hatai, kelle Dokumanın Türü: Taşpınar halısı

Dokumanın Tekniği: Türk Düğümü

Fotoğraf 21. Dokuma Örneği

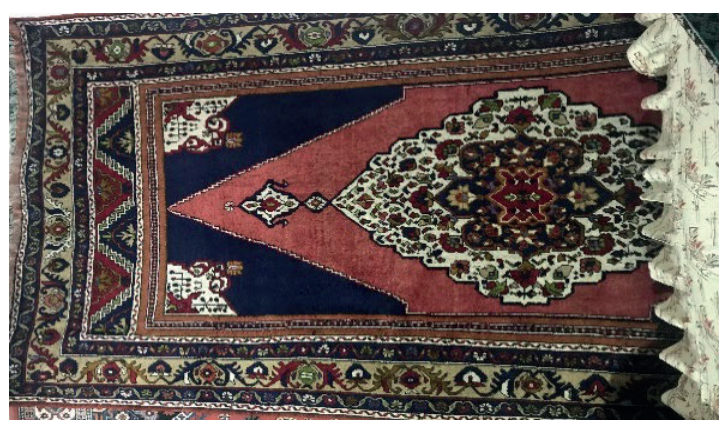

Kaynak: Kıllı̧ Karatay, 2021

Örnek 2.

Dokumanın Bulunduğu Yer: Hacı İbrahim Uşağı köyü Dokumanın Yöredeki İsmi: Yer halısı Dokumanın Yapıldığı Yıl: 1996

Dokumada Kullanılan Malzeme: Yün Kullanılan Motifler: Penç, hatai, kelle Dokumanın Türü: Taşpınar halısı

Dokumanın Tekniği: Türk Düğümü
Fotoğraf 22. Dokuma Örneği

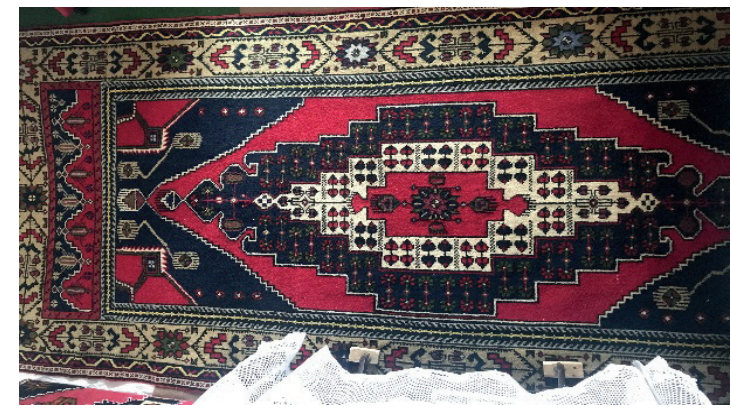

Kaynak: Kılıç Karatay, 2021

Örnek 3.

Dokumanın Bulunduğu Yer: Hacı İbrahim Uşağı köyü Dokumanın Yöredeki İsmi: Yer halısı Dokumanın Yapıldığı Yıl: 1994

Dokumada Kullanılan Malzeme: Yün

Kullanılan Motifler: Bereket, penç, hayat ağacı

Dokumanın Türü: Arısama halısı

Dokumanın Tekniği: Türk Dügüüü

Fotoğraf 23. Dokuma Örneği

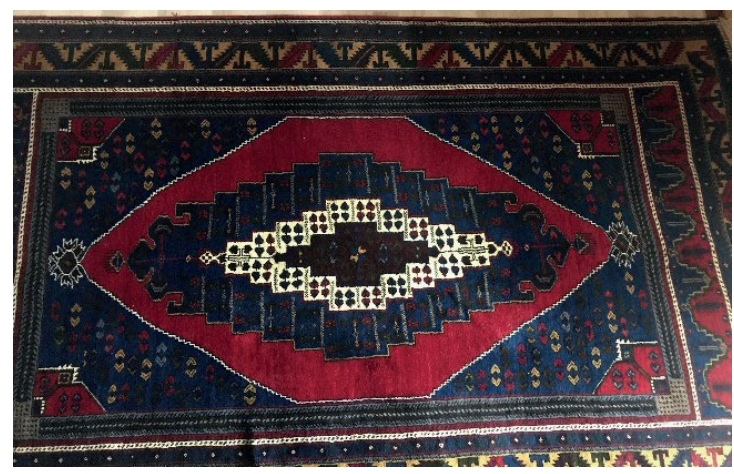

Kaynak: Kılıç Karatay, 2021

Örnek 4.

Dokumanın Bulunduğu Yer: Hacı İbrahim Uşağı köyü

Dokumanın Yöredeki İsmi: Yer halısı

Dokumanın Yapıldığı Yıl: 1998

Dokumada Kullanılan Malzeme: Yün

Kullanılan Motifler: Sandık,bukağı, hayat ağacı

Dokumanın Türü: Arısama halısı

Dokumanın Tekniği: Türk Düğümü 
Fotoğraf 24. Dokuma Örneği

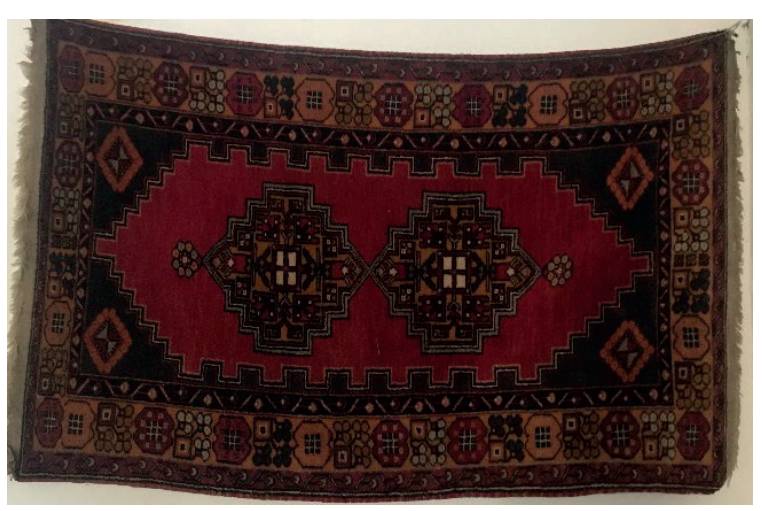

Kaynak: Kılıç Karatay, 2021

\section{Örnek 5.}

Dokumanın Bulunduğu Yer: Hacı İbrahim Uşağı köyü Dokumanın Yöredeki İsmi: Yer halısı

Dokumanın Yapıldığı Yıl: 1992

Dokumada Kullanılan Malzeme: Yün

Kullanılan Motifler: Göz, penç, top

Dokumanın Türü: Gelveri halısı

Dokumanın Tekniği: Türk Düğümü

Fotoğraf 25. Dokuma Örneği

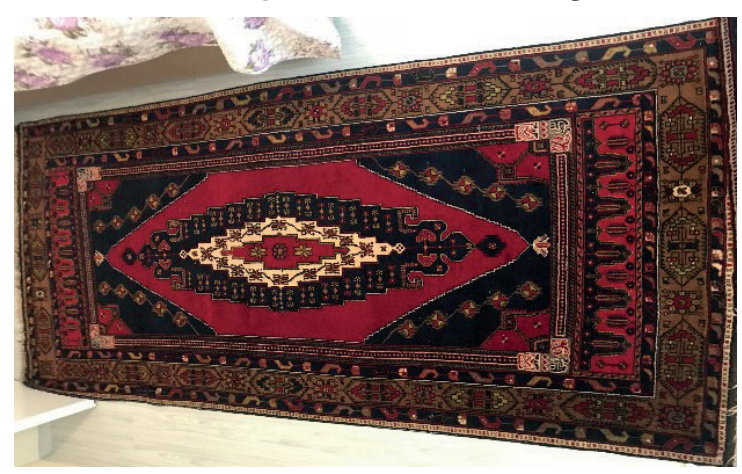

Kaynak: Kılıç Karatay, 2021

\section{Örnek 6.}

Dokumanın Bulunduğu Yer: Hacı İbrahim Uşağı köyü

Dokumanın Yöredeki İsmi: Yer halısı

Dokumanın Yapıldığı Yıl: 1998

Dokumada Kullanılan Malzeme: Yün

Kullanılan Motifler: Sandık,penç, hayat ağacı

Dokumanın Türü: Arısama halısı

Dokumanın Tekniği: Türk Düğümü
Fotoğraf 26. Dokuma Örneği

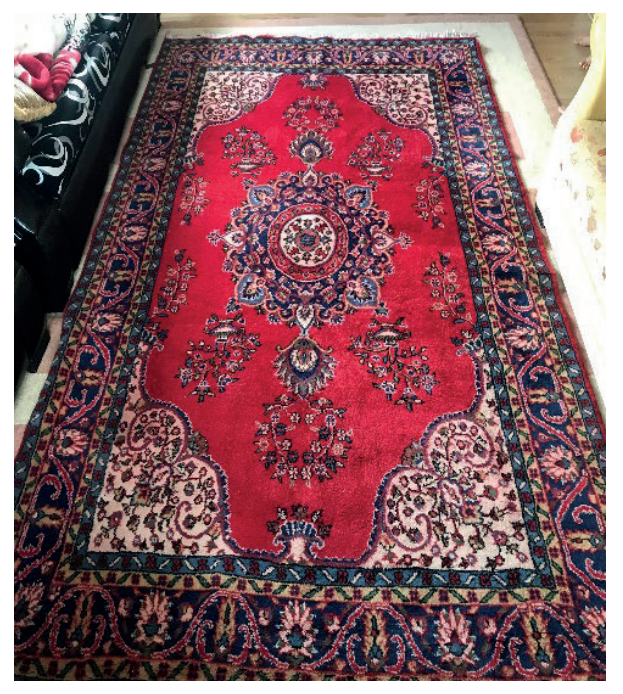

Kaynak: Kılıç Karatay, 2021

\section{Örnek 7.}

Dokumanın Bulunduğu Yer: Hacı İbrahim Uşağı köyü Dokumanın Yöredeki İsmi: Yer halısı

Dokumanın Yapıldığı Yıl: 1990

Dokumada Kullanılan Malzeme: Yün

Kullanılan Motifler: Penç, yaprak, hatai

Dokumanın Türü: Isparta halısı

Dokumanın Tekniği: Türk Dügüüü

\section{Fotoğraf 27. Dokuma Örneği}

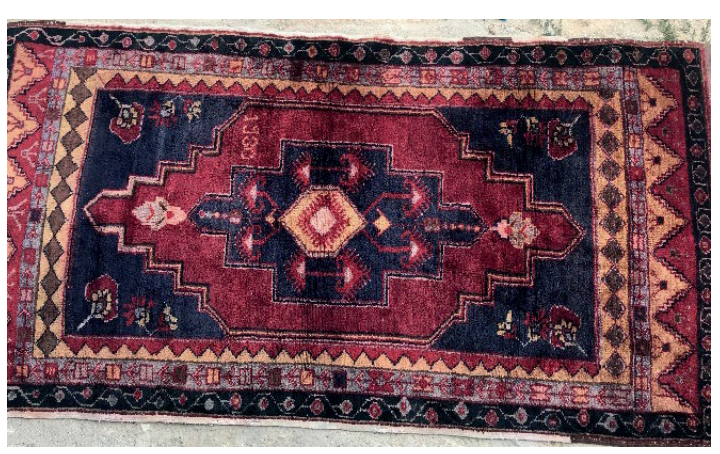

Kaynak: Kılıç Karatay, 2021

\section{Örnek 8.}

Dokumanın Bulunduğu Yer: Hacı İbrahim Uşağı köyü Dokumanın Yöredeki İsmi: Yer halısı Dokumanın Yapıldığı Yıl: 1974

Dokumada Kullanılan Malzeme: Yün

Kullanılan Motifler: Sandık, Pıtrak, Göz

Dokumanın Türü: Gelveri halısı

Dokumanın Tekniği: Türk Dügüüü 


\subsubsection{Yastık Dokuma Örnekleri}

Yastık olarak dokunan halı dokuma örnekleri olup içi saman hasırı ile doldurularak duvar kenarlarında dekorasyon süs eşyası olarak kullanılmaktadır. Zamanla eskiyen ya da yıpranan yastık dokumaları dikilerek veya yama yapılarak kapı önlerinde paspas olarak kullanılmaktadır (Altınpınar, 2021).

Dokumalar elde edildiği kaynak kişilerle yapılan görüşmelerde dokumaların anne veya babalarının çeyizinden hatta bazı dokuma örneklerinin ise anneanne ya da babaannenin çeyizinden kalma dokuma örnekleri olduğu görülmektedir. Dokumaların zamanla desen ve renk kompozisyonlarında yıpranma, yırtılma veya solmak görülmektedir ( Çiftçi, 20121).

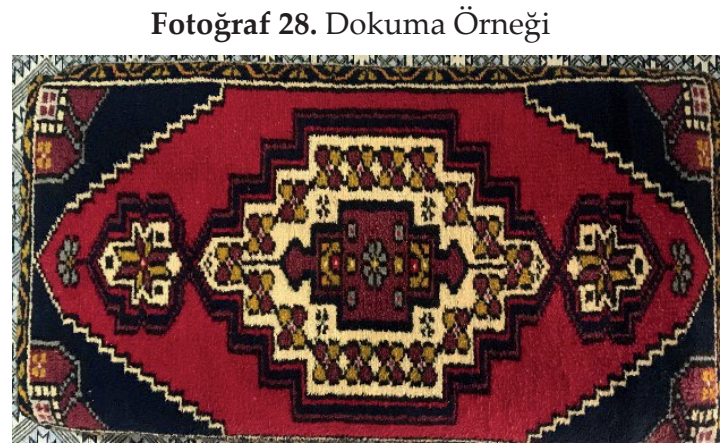

Kaynak: Kılıç Karatay, 2021

Örnek 1.

Dokumanın Bulunduğu Yer: Hacı İbrahim Uşağı köyü Dokumanın Yöredeki İsmi: Yastık

Dokumanın Yapıldığı Yıl: 2000

Dokumada Kullanılan Malzeme: Yün

Kullanılan Motifler: Penç, su yolu, yıldız

Dokumanın Türü: Halı dokuması

Dokumanın Tekniği: Türk düğümü

Fotoğraf 29. Dokuma Örneği

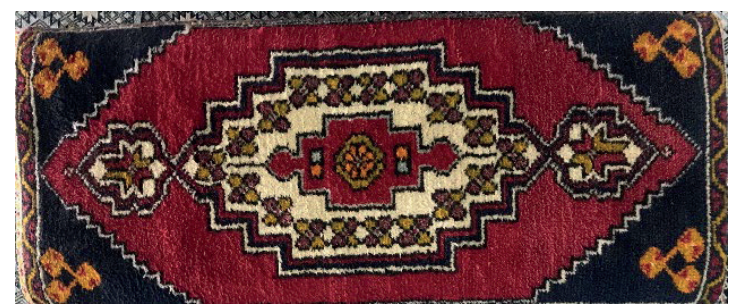

Kaynak: Kılıç Karatay, 2021

\section{Örnek 2.}

Dokumanın Bulunduğu Yer: Hacı İbrahim Uşağı köyü Dokumanın Yöredeki İsmi: Yastık

Dokumanın Yapıldığı Yıl: 2000
Dokumada Kullanılan Malzeme: Yün

Kullanılan Motifler: Penç, su yolu, yıldız

Dokumanın Türü: Halı dokuması

Dokumanın Tekniği: Türk dügüumü

Fotoğraf 30. Dokuma Örneği

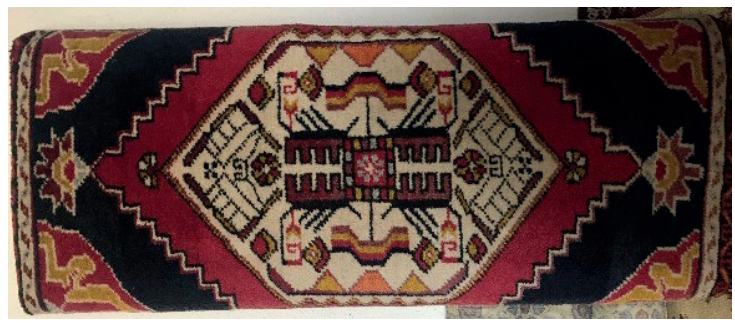

Kaynak: K1lı̧ Karatay, 2021

Örnek 3.

Dokumanın Bulunduğu Yer: Hacı İbrahim Uşağı köyü

Dokumanın Yöredeki İsmi: Yastık

Dokumanın Yapıldığı Yıl: 1995

Dokumada Kullanılan Malzeme: Yün

Kullanılan Motifler: Kelle, penç, hayat ağacı

Dokumanın Türü: Halı dokuması

Dokumanın Tekniği: Türk düğümü

\section{Fotoğraf 31. Dokuma Örneği}

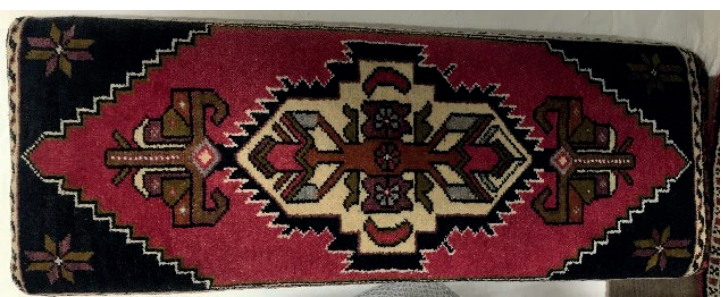

Kaynak: Kılıç Karatay, 2021

Örnek 4.

Dokumanın Bulunduğu Yer: Hacı İbrahim Uşağı köyü

Dokumanın Yöredeki İsmi: Yastık

Dokumanın Yapıldığı Yıl: 1997

Dokumada Kullanılan Malzeme: Yün

Kullanılan Motifler: Elibelinde, koç boynuzu, yıldız

Dokumanın Türü: Halı dokuması

Dokumanın Tekniği:Türk düğümü 
Fotoğraf 32. Dokuma Örneği

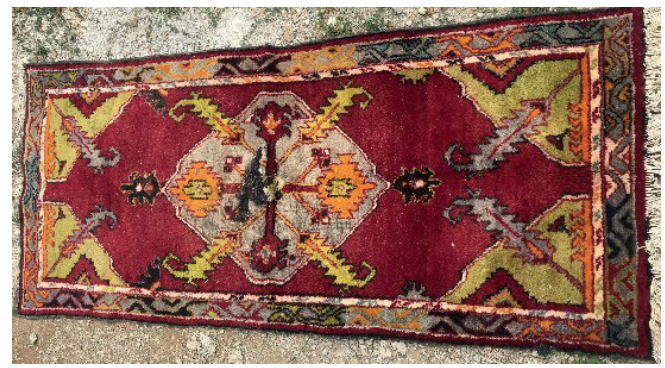

Kaynak: Kılıç Karatay, 2021

\section{Örnek 5.}

Dokumanın Bulunduğu Yer: Hacı İbrahim Uşağı köyü Dokumanın Yöredeki İsmi: Yastık

Dokumanın Yapıldığı Yıl: 1973

Dokumada Kullanılan Malzeme: Yün

Kullanılan Motifler: Yaprak, su yolu, kelle

Dokumanın Türü: Halı dokuması

Dokumanın Tekniği: Türk düğümü

\section{Fotoğraf 33. Dokuma Örneği}

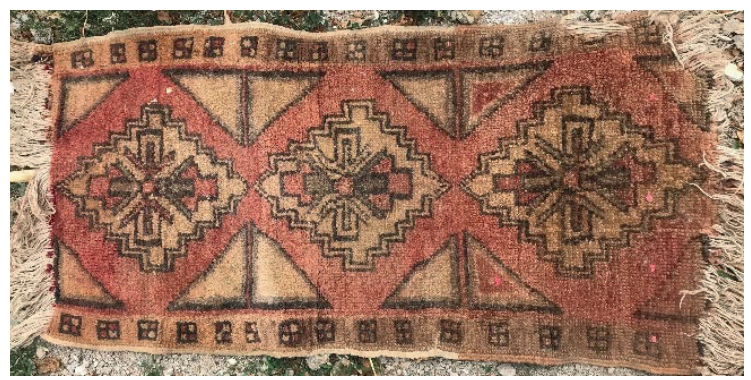

Kaynak: Kılıç Karatay, 2021

\section{Örnek 6.}

Dokumanın Bulunduğu Yer: Hacı İbrahim Uşağı köyü

Dokumanın Yöredeki İsmi: Yastık

Dokumanın Yapıldığı Yıl: 1972

Dokumada Kullanılan Malzeme: Yün

Kullanılan Motifler: Bereket, penç, muska

Dokumanın Türü: Halı dokuması

Dokumanın Tekniği: Türk düğümü
Fotoğraf 34. Dokuma Örneği

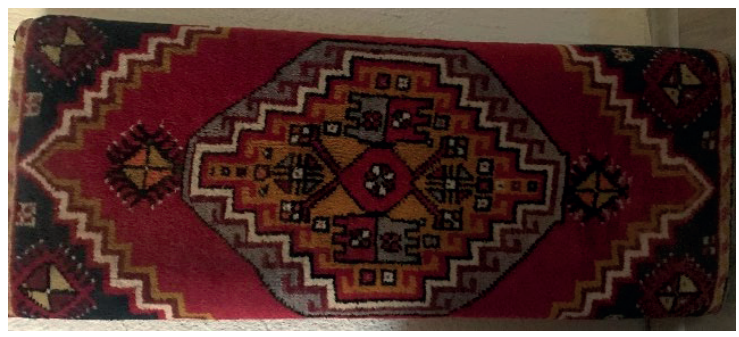

Kaynak: Kılıç Karatay, 2021

\section{Örnek 7.}

Dokumanın Bulunduğu Yer: Hacı İbrahim Uşağı köyü

Dokumanın Yöredeki İsmi: Yastık

Dokumanın Yapıldığı Yıl: 1980

Dokumada Kullanılan Malzeme: Yün

Kullanılan Motifler: Pitrak, penç, göz

Dokumanın Türü: Halı dokuması

Dokumanın Tekniği: Türk düğümü

Fotoğraf 35. Dokuma Örneği

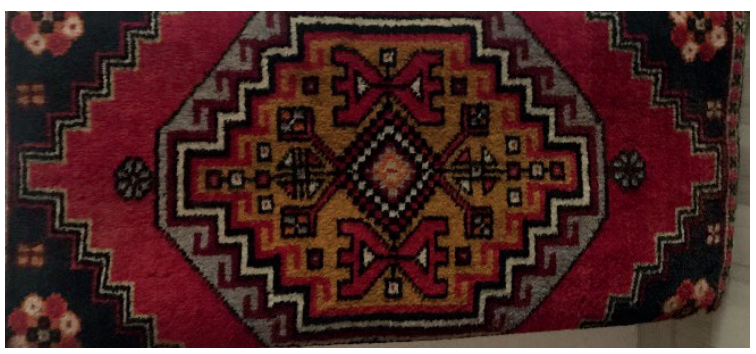

Kaynak: Kılıç Karatay, 2021

Örnek 8.

Dokumanın Bulunduğu Yer: Hacı İbrahim Uşağ köyü

Dokumanın Yöredeki İsmi: Yastık

Dokumanın Yapıldığı Yıl: 1984

Dokumada Kullanılan Malzeme: Yün

Kullanılan Motifler: Bereket, göz, Penç

Dokumanın Türü: Halı dokuması

Dokumanın Tekniği: Türk düğümü 
Fotoğraf 36. Dokuma Örneği

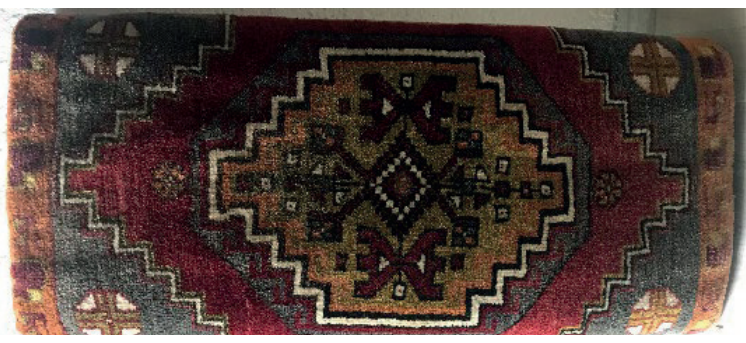

Kaynak: K1lıç Karatay, 2021

Örnek 9.

Dokumanın Bulunduğu Yer: Hacı İbrahim Uşağı köyü Dokumanın Yöredeki İsmi: Yastık

Dokumanın Yapıldığı Yıl: 1988

Dokumada Kullanılan Malzeme: Yün

Kullanılan Motifler: Göz, Penç, Bereket

Dokumanın Türü: Halı dokuması

Dokumanın Tekniği: Türk düğümü

Fotoğraf 37. Dokuma Örneği

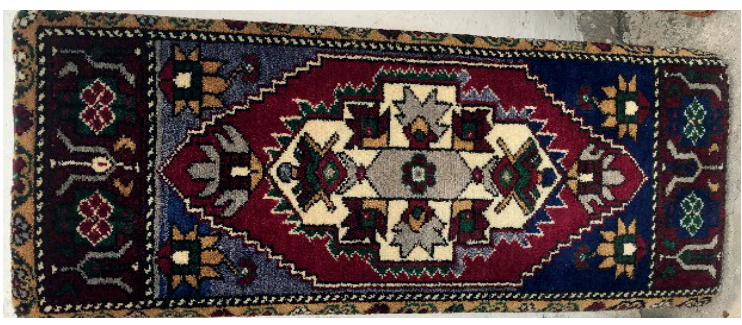

Kaynak: Kılıç Karatay, 2021

\section{Örnek 10}

Dokumanın Bulunduğu Yer: Hacı İbrahim Uşağı köyü Dokumanın Yöredeki İsmi: Yastık

Dokumanın Yapıldığı Yıl: 1997

Dokumada Kullanılan Malzeme: Yün

Kullanılan Motifler: Kelle, penç, hatai

Dokumanın Türü: Halı dokuması

Dokumanın Tekniği: Türk düğümü

Fotoğraf 38. Dokuma Örneği

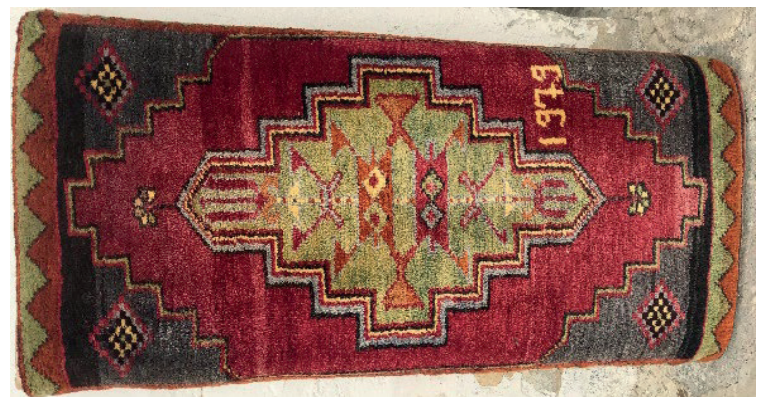

Kaynak: Kılıç Karatay, 2021

Örnek 11.

Dokumanın Bulunduğu Yer: Hacı İbrahim Uşağı köyü
Dokumanın Yöredeki İsmi: Yastık

Dokumanın Yapıldığı Yıl: 1979

Dokumada Kullanılan Malzeme: Yün

Kullanılan Motifler: Göz, koç boynuzu, göz

Dokumanın Türü: Halı dokuması

Dokumanın Tekniği: Türk düğümü

Fotoğraf 39. Dokuma Örneği

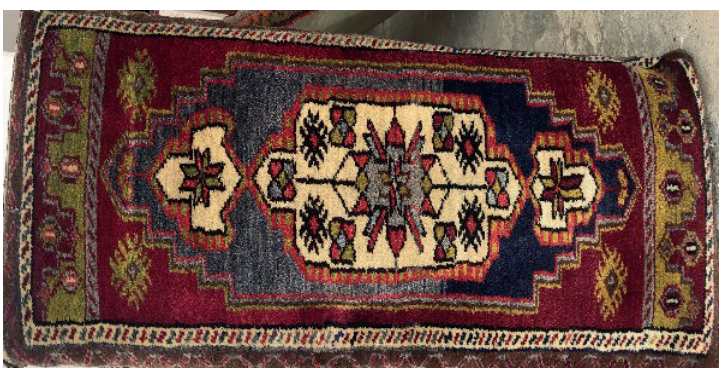

Kaynak: Kılıç Karatay, 2021

\section{Örnek 12.}

Dokumanın Bulunduğu Yer: Hacı İbrahim Uşağı köyü Dokumanın Yöredeki İsmi: Yastık

Dokumanın Yapıldığı Yıl: 1995

Dokumada Kullanılan Malzeme: Yün

Kullanılan Motifler: Pıtrak, yıldız, hayat ağacı

Dokumanın Türü: Halı dokuması

Dokumanın Tekniği: Türk düğümü

Fotoğraf 40. Dokuma Örneği

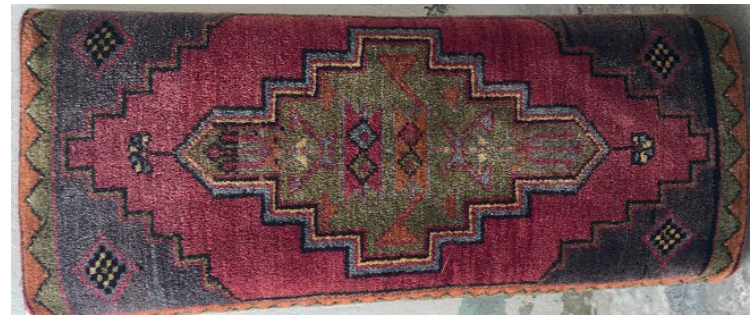

Kaynak: Kılıç Karatay, 2021

\section{Örnek 13.}

Dokumanın Bulunduğu Yer: Hacı İbrahim Uşağı köyü Dokumanın Yöredeki İsmi: Yastık

Dokumanın Yapıldığı Yıl: 1979

Dokumada Kullanılan Malzeme: Yün

Kullanılan Motifler: Göz, Koç boynuzu, küpe

Dokumanın Türü: Halı dokuması

Dokumanın Tekniği: Türk düğümü 
Fotoğraf 41. Dokuma Örneği

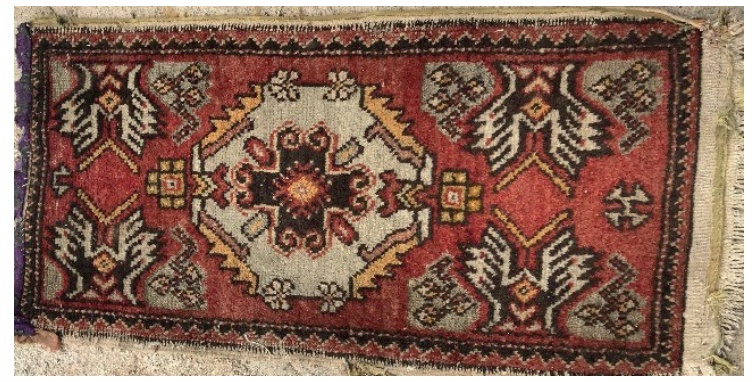

Kaynak: Kılıç Karatay, 2021

Örnek 14.

Dokumanın Bulunduğu Yer: Hacı İbrahim Uşağı köyü Dokumanın Yöredeki İsmi: Yastık

Dokumanın Yapıldığı Yıl: 1980

Dokumada Kullanılan Malzeme: Yün

Kullanılan Motifler: Koç boynuzu, göz, hayat ağacı

Dokumanın Türü: Halı dokuması

Dokumanın Tekniği: Türk düğümü

Fotoğraf 42. Dokuma Örneği

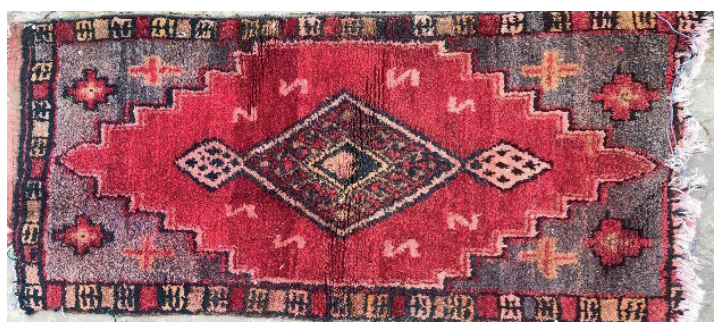

Kaynak: Kılıç Karatay, 202

Örnek 15.

Dokumanın Bulunduğu Yer: Hacı İbrahim Uşağı köyü

Dokumanın Yöredeki İsmi: Yastık

Dokumanın Yapıldığı Yıl: 1972

Dokumada Kullanılan Malzeme: Yün

Kullanılan Motifler: Göz, su yolu, bereket

Dokumanın Türü: Halı dokuması

Dokumanın Tekniği: Türk düğümü
Fotoğraf 43. Dokuma Örneği

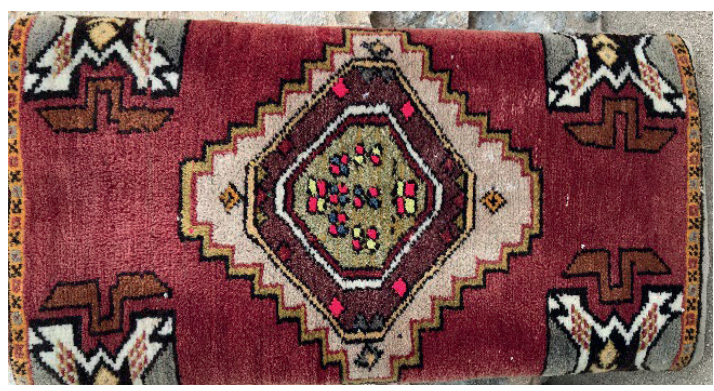

Kaynak: Kılıç Karatay, 2021

\section{Örnek 16.}

Dokumanın Bulunduğu Yer: Hacı İbrahim Uşağı köyü Dokumanın Yöredeki İsmi: Yastık

Dokumanın Yapıldığı Yıl: 1980

Dokumada Kullanılan Malzeme: Yün

Kullanılan Motifler: Göz, koç boynuzu, su yolu

Dokumanın Türü: Halı dokuması

Dokumanın Tekniği: Türk düğümü

Fotoğraf 44. Dokuma Örneği

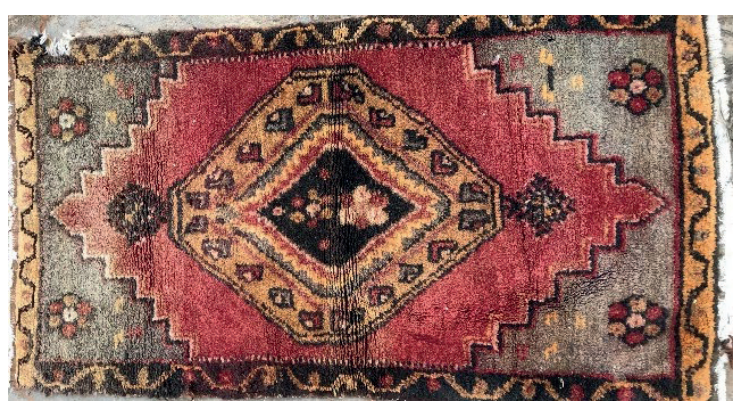

Kaynak: Kılıç Karatay, 2021

\section{Örnek 17.}

Dokumanın Bulunduğu Yer: Hacı İbrahim Uşağı köyü Dokumanın Yöredeki İsmi: Yastık

Dokumanın Yapıldığı Yıl: 1978

Dokumada Kullanılan Malzeme: Yün

Kullanılan Motifler: Penç, kelle,su yolu

Dokumanın Türü: Halı dokuması

Dokumanın Tekniği: Türk dügüüü 
Fotoğraf 45. Dokuma Örneği

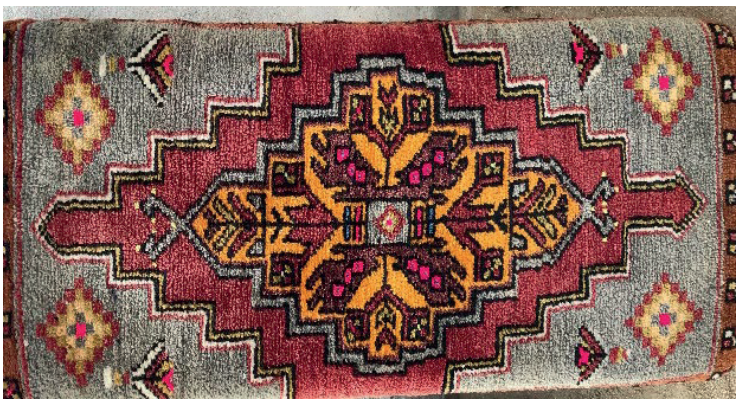

Kaynak: Kılıç Karatay, 2021

Örnek 18.

Dokumanın Bulunduğu Yer: Hacı İbrahim Uşağı köyü

Dokumanın Yöredeki İsmi: Yastık

Dokumanın Yapıldığı Yıl: 1974

Dokumada Kullanılan Malzeme: Yün

Kullanılan Motifler: Göz, penç, hayat ağacı

Dokumanın Türü: Halı dokuması

Dokumanın Tekniği: Türk düğümü

Fotoğraf 46. Dokuma Örneği

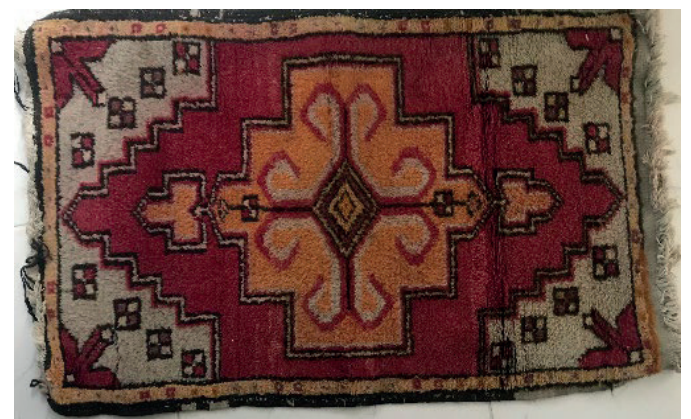

Kaynak: Kılıç Karatay, 2021

\section{Örnek 19.}

Dokumanın Bulunduğu Yer: Hacı İbrahim Uşağı köyü

Dokumanın Yöredeki İsmi: Yastık

Dokumanın Yapıldığı Yıl: 1990

Dokumada Kullanılan Malzeme: Yün

Kullanılan Motifler: koç boynuzu, göz, boncuk

Dokumanın Türü: Halı dokuması

Dokumanın Tekniği: Türk düğümü

\section{SONUC}

Dokuma, Anadolu insanının geçmişten bugüne ulaşabilen en önemli kültür değerlerinden biridir. İnsanoğlu yaşamını devam ettirmek adına birçok sanat alanında değişime ve zamanla zengin kültür birikimine sahip olmuştur. Günümüze kadar ulaşabilen örnekler dokundukları dönemin kültürünü yansıtarak bizlere bilgi kaynağı olmaktadır.

Aksaray -Ortaköy ilçesine bağlı Hacı İbrahim Uşağı Köyünde elde edilen halı ve kilim dokuma örnekleri bir dönem köyde dokumanın yapıldığını, dokuma sanatının köyde gelişmiş olduğunu göstermektedir. Köyde elde edilen örnekler doğrultusunda inceleme yapıldığında dokumalarda kullanılan desen kompozisyonların göç kültürü ile geldiği ve Aksaray'ın birçok bölgesinde dokunan kompozisyonların kullanıldığ görülmektedir. Dokumalar dokunma tarihi bakımından değerlendirildiğinde en yakın dokumanın 2000'li yıllara dayandığı ve günümüzde dokumanın yapılmadığı görülmektedir.

Köyde bulunan dokumalar halı ve kilim olarak iki grupta incelenmiş, dokumalar kendi gruplarında s1nıflandırılmıştır. Halı dokuma örnekleri yer ve yastık halısı, düz dokuma örnekleri ise yer, çuval ve heybe dokuma örnekleri olarak incelenmiştir. Dokumaların çeyiz olarak yapıldığı ve miras yoluyla şimdiki sahiplerine kaldığı tespit edilmiştir. Günümüzde dokumanın yapılmadığı köyde dokumanın yapılmaması, genç neslin dokuma sanatına ilgi duymaması kültür değerlerimizin unutulup kaybolmaya yüz tuttuğunun bir göstergesidir. Ayrıca elde edilen dokuma örneklerinin birçoğunun bilgisizce yıkanması ve ya kullanılması da yine bu değerli varlıklarımızın değerini kaybetmesine neden olmuştur. Bir dönem dokumanın yapıldığı köyde dokuma örnek sayısının çok fazla olduğu ancak zamanla bu dokuma örneklerinin maddi destek amaçlı satıldı ğı veya evlerde kullanılmak üzere makine halıları ile değişim yapıldı̆̆ 1 araştırma sonucunda elde edilen sonuçlardan biridir. Bu durum köydeki dokuma sahiplerinin dokumalarının değeri hakkında yeterince bilgi sahibi olmadıklarını da göstermektedir. Köyde yaşayan insan nüfusun okuryazarlık seviyesinin yükselmesi ve işsizlik sorununun az olması bu kültür değerimizin unutulmasına sebep olmuştur.

\section{KAYNAKÇA}

ARSEVEN, C. E. (1980). Türk Sanat, İstanbul.

ASLANAPA, O. (2005). Türk Halı Sanatının Bin Yıll, Ankara: İnkılap Kitabevi.

YETKIN, S. (1991). Türk Halt Sanat, Ankara.

YETKIN Ș. (1974). Türk Halı Sanatı, İstanbul: Çağlayan Basımevi. 
KILIÇ KARATAY S. (2018), Aksaray İli Sultanhanı'nda Halıcılık ve Halı Restorasyonu, Sanatta Yeterlilik Tezi, Süleyman Demirel Üniversitesi, Güzel Sanatlar Enstitüsü

ALTINPINAR, H. (15.08.2021). Hacı İbrahim Uşağı Köyü ALTINPINAR, Z. (15.08.2021). Hacı İbrahim Uşağı Köyü

ÇİFTÇİ, A. (15.08.2021). Hacı İbrahim Uşağı Köyü

ÇiFTÇİ, G. (15.08.2021). Hacı İbrahim Uşağı Köyü

ÇíFTÇİ, S. (15.08.2021). Hacı İbrahim Uşağı Köyü

DUMAN, M. (11.08.2021). Hacı İbrahim Uşağı Köyü

EĞRITAŞ, A. (11.08.2021). Hacı İbrahim Uşağı Köyü

KOCAGÜL, Y. (11.08.2021). Hacı İbrahim Uşağı Köyü

SERGIKAYA, İ. (21.07.2021). Hacı İbrahim Uşağı Köyü

SERGIKKAYA, R. (15.08.2021). Hacı İbrahim Uşağı Köyü

SERGIKKAYA, F. (21.07.2021). Hacı İbrahim Uşağı Köyü

SERGIKAYA, S. (21.07.2021). Hacı İbrahim Uşağı Köyü 